EGU2020-9131

https://doi.org/10.5194/egusphere-egu2020-9131

EGU General Assembly 2020

(c) Author(s) 2020. This work is distributed under

the Creative Commons Attribution 4.0 License.

\title{
Microbial metabolic activity measurements in clouds and precipitation at the puy de Dôme station (Central France)
}

\author{
Florent Rossi ${ }^{1}$, Raphaëlle Péguilhan ${ }^{1}$, Maxence Brissy ${ }^{1}$, Laurent Deguillaume ${ }^{2}$, Anne-Marie Delort ${ }^{1}$, \\ and Pierre Amato ${ }^{1}$ \\ ${ }^{1}$ Université Clermont Auvergne, CNRS, SIGMA Clermont, ICCF, F-63000 CLERMONT-FERRAND, FRANCE \\ ${ }^{2}$ Université Clermont Auvergne, CNRS, OPGC, F-63000 CLERMONT-FERRAND, FRANCE
}

Airborne bacteria are important components of biological aerosols. They have been shown to remain alive and metabolically active in the different compartment of the atmosphere (clouds, rain, aerosols), despite the harsh environmental conditions (U.V., free radicals, low temperatures, etc...). Current knowledge indicates that bacteria interfere with chemical reactivity in clouds, by utilizing carbon and nitrogen compounds, detoxifying free radicals and their precursors, etc. Nevertheless, due to the low biomass $\left(\approx 10^{2}\right.$ to $\approx 10^{6}$ cells $\left./ \mathrm{m} 3\right)$ and numerous sampling constraints, bacterial activity remains largely unexplored in atmospheric water; and regarding atmospheric chemistry, airborne bacteria are still essentially regarded as inert particles.

To fulfill this gap in knowledge, this study aims at quantifying microbial activity in the different compartments of the atmosphere. Sampling and analytical methods were developed and adapted to overcome the low biomass constraint and the required immediate analyses, to obtain in situ quantitative and qualitative measurements of biological activity. Samplings of cloud water were performed between September 2019 and April 2020 at the Puy de Dôme Mountain's meteorological station (1465 m asl, France) using impactors and high-flow-rate impingers [1], whereas precipitations were collected below the summit (Opme station, $680 \mathrm{~m}$ asl) using an automated wet-deposition sampler. Bacterial metabolic activity was assessed by coupling two different approaches: the determination of the active fraction of bacteria using the ubiquitous esterase enzyme activity as proxy (fluorescein diacetate assay, flow cytometry), and the quantification of ribosomal DNA/RNA (qPCR). Relationship between these activities and meteorological, physical and chemical measurements were also examined.

Preliminary results showed traces of a recent metabolic activity in cloud's bacterial communities, as highlighted by the observed rRNA/rDNA ratio of 1 . In parallel, $8.5 \%$ of the bacteria in clouds exhibited an esterase activity, supporting that bacteria can remain active in clouds. The bacterial fraction displaying esterase activity in precipitation samples was much higher (30\%), suggesting fast variations in bacterial metabolic activity, probably related with changes in environmental constraints and bacterial assemblage composition. Further investigations are on-going to specify microbial activity along the aerosol-cloud-precipitation continuum, its variability, and to quantify its contribution to atmospheric chemical processes. 
[1] T. Šantl-Temkiv et al., "High-Flow-Rate Impinger for the Study of Concentration, Viability, Metabolic Activity, and Ice-Nucleation Activity of Airborne Bacteria," Environ. Sci. Technol., vol. 51, no. 19, pp. 11224-11234, 2017. 